\title{
Financial Management Overview
}

\author{
Cihat Burak Zorlu \\ Hult International Business School
}

Understanding the decision-making process for businesses are very important. There are many financial aspects of decision-making process, but managers need to think about only three concepts; How to finance decisions, how to invest in decisions and how to dividend decisions. While making decisions, managers need to master subject Time Value of Money. Time value of money concept will increase the success of the investments, because managers will be more aware of the net present value concepts. As a result of mastering the subject of TVM, managers can maintain a healthy balance between the return and risk in order to maximize the market value of the business.

Keywords: time value of money, net present value, decision making, managerial finance, capital Budgeting, capital structure, working capital management

\section{DECISION MAKING PROCESS IN FINANCIAL MANAGEMENT}

Businesses must maintain a steady Financial Managerial plan to survive in the volatile and unstable business environment. Financial management is the management of the financial aspects such as; tools and investments in order for businesses to achieve their financial goals. Three most important targets for companies are; maximizing the value of the company, maximizing the profit of the company and maintaining sufficient investing activities. The value of the firm is equal to the value of equity and debt claims (Chandra, 2011). Decision process for businesses is not only affected by the preferences made by the managers but there are also environmental factors affecting the efficiency and planning of the financial decisions. These factors can be; change in the demand and/or willingness by the customers, financial crisis, competitive environment and technological changes. Financial management is an agent to forecast financial requirements, raise funds, control over funds and coordination of the activities. (Table 1.)

TABLE 1

MEANING OF FINANCIAL MANAGEMENT

\begin{tabular}{l|l}
\hline Forecasting of financial requirement & Control over utilization of funds \\
- Fixed Capital & - Laying down policies \\
- Working Capital & - Monitoring of actual Performance \\
Raising of funds & - Identifying deviations \\
- Shares & - Corrective measures \\
- Debentures & Coordination of diverse activities \\
- Bank loans & - Cost control \\
\hline
\end{tabular}

172 Journal of Applied Business and Economics Vol. 22(12) 2020 
- Loans from financial institution

- Public deposits

- Retained earning
- Pricing

- Management of assets and funds

Businesses' create value through their business decisions. Investing, Operating and Financing decisions affects the value of the business. Value is created for investors and shareholders. Value and attractiveness of the company has a positive correlation. However, timing of the actions to increase value are very important. Time is a crucial factor in the finance. Because of that businesses and managers must understand the concept of Time Value of Money (TVM).

\section{TIME VALUE OF MONEY}

TVM is the concept that the value of the same amount of unit money coming in the future is less than the value of the same amount of unit today (Rahman, 2017). Theory states that having money today is better than tomorrow. The reason for this assumption is the potential earning capacity between today and tomorrow. In countries where there are high inflation rates, due to decrease in the purchasing power, people believe that there is a connection between inflation and TVM. However, they are two independent concepts. Even though the inflation rate is 0 , a unit of money today is more valuable than a unit money tomorrow. In this environment where inflation is 0 , nominal interest rate $=$ real interest rate* inflation.

In a business, manager must know the TVM in order to plan their payments and receivables accordingly. Planning and investing according to TVM is important for businesses to create more value with less capital. While comparing financial, investing or operating actions, it is important to compare the values at the same timeline. Discounting Future Value (FV) to find Present (PV) and Net Present Value (NPV) gives companies opportunity to compare values in the same timeline. NPV is the difference between PV and the value which the financial tools can be bought in the market. NPV measures the creation and the demolition of value the action. In order to create value NPV must be bigger than 0 . Changes in NPV and PV move in opposite directions with the discount factor because discount factor indicates the risk involved in the project or action. Even though there are several other valuation concepts -intrinsic value, market value, book value, future value, terminal value, fair value- PV is the most reliable in terms of calculations. PV includes most of the elements considered to be important in the business like; capital investment, risk factors, WACC, operating/ financing/ investing performance.

\section{DECISION MAKING PROCESS}

There are 3 financial decisions managers need to think about: Financing Decisions, Investment Decisions and Dividend Decisions. Decisions are important from the point of view of the internal working for the firm and also from the point of view which outsiders take of the firm. Managers must maintain a healthy balance between the return and risk in order to maximize the market value of the business (Sharma \& Kumar, 1998) (Figure 1). 


\section{FIGURE 1}

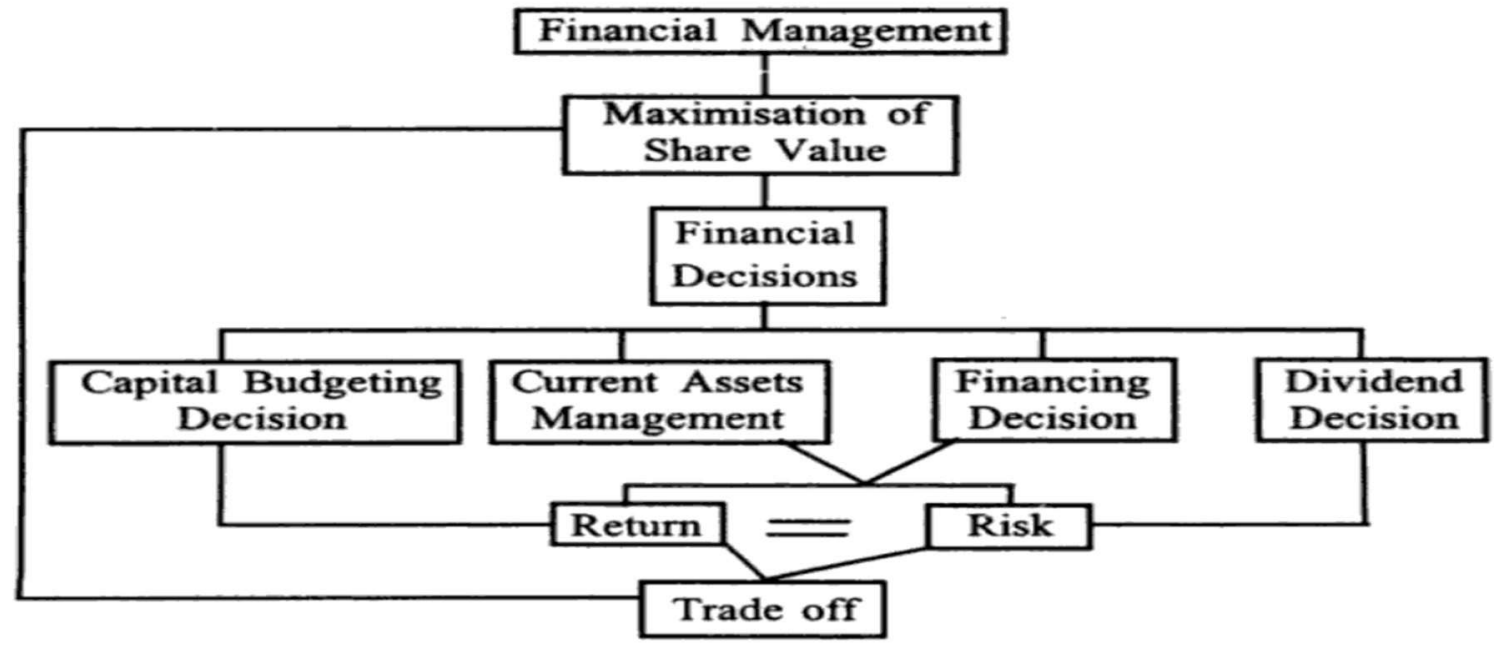

There are three broad areas of financial decisions: Capital Budgeting, Capital Structure and Working Capital Management.

\section{Capital Budgeting}

Capital budgeting is probably the most important decision in the financing decision process. The reason for that is, capital budgeting is the plan for business how to allocate their capital for their future and ongoing plans. Investing in tangible and long-term assets increase the value of the business. However, when looking at an investment project from the financial point of view, focusing on the magnitude, time and risk factor are important (Chandra, 2011). Taking poor capital investment decisions can have a disastrous effect on the business (Carlson, 2020).

Funds available to be invested in a business is either an equity or a debt and also referred as capital (Bradshaw, n.d.). There are limited capital and investment opportunities for businesses. Investing in the most efficient and profitable investment is very important for the future of the business. Allocation of the scarce capital is important due to limitations. As mentioned above TVM must be considered while capital budgeting. NPV must be positive to generate value for the business. Hence the ROI will be bigger than its cost.

While investing in a long-term asset, business must follow several steps to find out how much value will generate that specific investment. First of all, business must determine total amount of capital investment. Secondly, business must estimate how much value will the action create that affects the cash flow also considering with TVM. Business can estimate the cash flow the investment will return. Thirdly, calculating the residual or terminal value. Residual value is the estimated value of an asset at the end of useful time (Tuovila, 2020). But if there is no ending time or estimation for the useful time managers must use Terminal value. Terminal value assumes the value at the end of the last cash flow will perpetually continue. Another way to find out terminal value is $\mathrm{EBITDA}^{*}(\mathrm{P} / \mathrm{E})$. Because $\mathrm{P} / \mathrm{E}$ ratio is a great deterministic to understand growth. Discounting the perpetual value will give the terminal value of the present. With the previous three steps cash flow amounts can be determined. Furthermore, calculation of the NPV is necessary to understand the performance. Discounting the cash flow of " $n$ " years will give the PV of Cash flow. Sum of all PV of Cash flows will give managers the NPV.

WACC is a benchmark for value creation. Cost of Capital is the required return necessary to make a capital budgeting project (Kenton, 2019). WACC is the cost to increase the capital in a business. In order for a business to generate value WACC must be small or equal to the Rate of return asked. WACC allows businesses to calculate value easier with Modigliani- Miller Theorem. 
Companies enhance their value by getting debt because debt is cheap to get. Borrowing increases the value of the company. Debt shows to potential investors and shareholders that, business has a connection with the financial market. (Figure 2)

\section{FIGURE 2 VALUE/DEBT GRAPHIC}

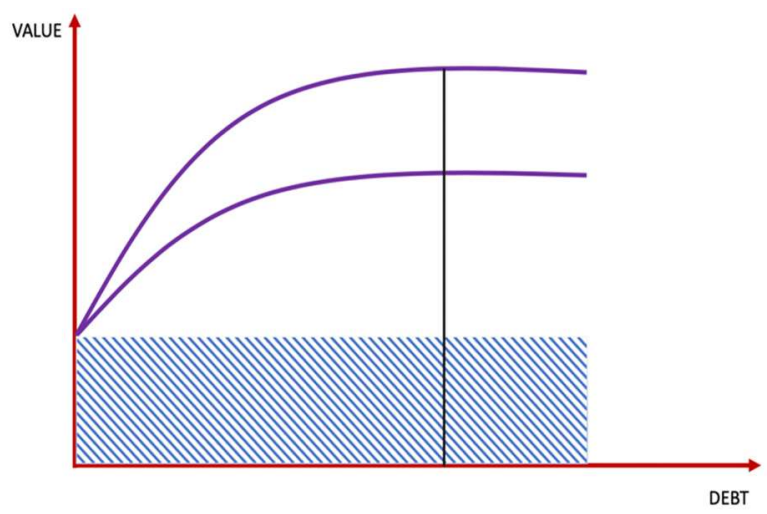

\section{Capital Structure}

Investing in projects and action increases the value of the business. Managers should decide on how to finance investments. Main goal for managers while maintaining the sustainable environment for value creation is minimizing the cost of financing. Managers must understand questions like;

- What is the optimal debt/ equity ratio?

- What financial tools the business should use?

- Which capital markets should the business access?

Debt and equity are used to fund capital expenditures. The balance between two concepts and finding the optimal ratio will increase the value of the company in the long run. As mentioned above, borrowing increases value. But in what way business should borrow.

\section{Debt}

Debt states that business is connected to the market. Debt investors take less risk because they are first group to take their assets in case of a bankruptcy or any event of liquidation. Due to low risk involved, rate of return is less as opposed to equity investors. Debt is cheaper than equity because interest payments are tax deductible expense (Miller, 2019). Hence, some private equity firms buy high debt dependent businesses to take advantage of tax shield.

Debt capital can be divided into two subsections: loans and bonds. Loans are type of debt obtained by an organization like bank with requirement to payback the initial principal with interest. They can be either long-term or short-term. Initializing capital by getting loan and paying interest must be calculated by the manager. Sometimes rate of return required by the lender can be too much. That's why financial statements should be shared with the other party. The second way to get debt is to issue bonds, bills or notes. They are types of instruments to get debt by issuing a paper with an initial principal and with payments until the maturity time (Chen, 2020). Coupon payments percentages are set by the buyer of the bond according to the risk involved. Why people buy bonds? Bonds are mostly secure investments and can be bought smaller price than the face value. For instance, if a business has bonds and they need cash, buyer can buy the bond cheaper. Most government bonds are $0 \%$ coupon rate and very expensive. Buyer of the bond can gain value by two ways. One is the coupon payments and the second is the price between the price and the face value of the bond. Why debt financing is important for businesses? TVM concept states that money today is more valuable than money tomorrow. Having the money right now will open up new opportunities for the business. However, fixed payments and having specific timeline are disadvantages of having a debt capital. 


\section{Equity}

Equity capital is defined as investment of the money by the shareholders of the business. First of all, initial investment as we refer contributed capital which is selling of the shares outstanding to investors. Secondly, showing of profits, retained earnings and a solid balance sheet to attract potential buyers to capitalize growth and power of the business. The cost of equity capital is higher than debt because shareholders and investors are the last stakeholders to collect assets in case of a bankruptcy or a liquidation process. As a result, risk factor creates higher rate of return. Investors also have the right to vote while managing business. Taking more equity may generate more power to the shareholders and investors. On the other hand, some advantages of equity are; there are no interest or coupon payments, no mandatory fixed payments, no maturity dates or specific timeline.

Most efficient allocation of the $\mathrm{D} / \mathrm{E}$ is when the cost of capital is minimized, and the value created is maximized (Figure 3). Using equity to buy assets is referred as using lower leverage while using debt is considered as higher leverage (Miller, 2019).

FIGURE 3

\section{DEBT TO EQUITY RATIO}

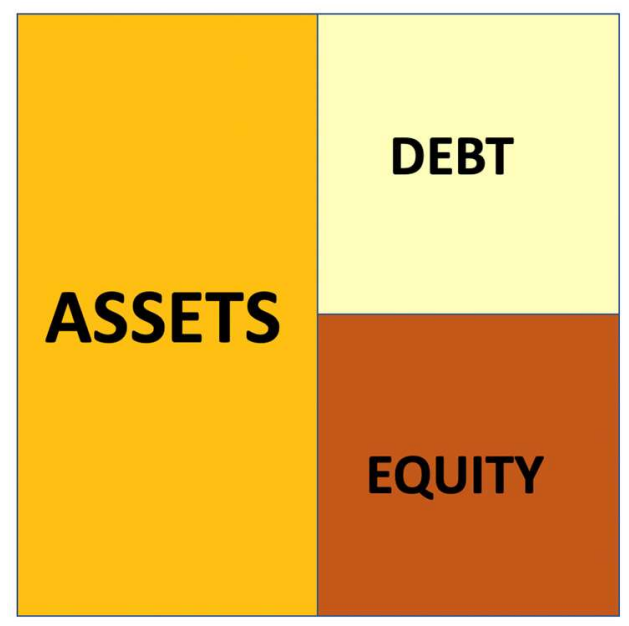

\section{Working Capital Management}

Refers to the short-term financial statement and interested in the daily financial activities and currents assets. Key issue is to understand the most efficient level of current assets especially inventory for operations. How much cash should the business have in hand?

Working capital management is a key to show the efficiency, liquidity and overall performance of the company to investors. Managing a healthy business and working capital results in better performance and eventually result in higher revenue and income. Smoother operations of projections must be done with less cost. Managers should consider potential additional costs and plan according to the possible problems. The main objectives of working capital management include maintaining the working capital cycle and maximizing the return on current asset investments (Hawley, 2019). Working capital generates the revenue to cover debts and payments such as coupon payments or interest payments.

\section{CONCLUSION}

Financial managers should consider potential risks involved in the business and plan according to those risk. Eventually managers should understand how to generate higher value for the business. For whom managers should generate this value. According to Michael Jensen, there is a positive correlation between maximizing the value for the company and also for the society (Jensen, 1997). Value creation goes through several steps and each step has potential risks involved. Financial managers should allocate scarce resources 
like money to their most productive use and most efficient users by obtaining those resources in a low cost (Stewart, 1991.)

\section{REFERENCES}

Bradshaw, D. (n.d.). Justifying Investments with the Capital Budgeting Process. Retrieved from https://www.toptal.com/finance/budgeting/capital-budgeting-process

Carlson, R. (2020). What is Capital Budgeting and Why is it Important in Business? Retrieved from https://www.thebalancesmb.com/capital-budgeting-and-its-importance-in-business-392912

Chandra, P. (2011). Financial Management (8th Edition). McGraw Hill Education. New Delhi.

Chen, J. (2020). Debt Financing. Retrieved from https://www.investopedia.com/terms/d/debtfinancing.asp

Hawley, J. (2019). Why Working Capital Management Matters. Retrieved from https://www.investopedia.com/ask/answers/100715/why-working-capital-management-importantcompany.asp

Jensen, M. (1997). The Nature of Man. Economist.

Kenton, W. (2019). Cost of Capital Definition. Retrieved from https://www.investopedia.com/terms/c/costofcapital.asp

Kumar, A., \& Sharma, R. (1998). Financial Management Theory and Practice. Atlantic Publishers and Distribution. New Delhi- 110027

Miller, T. (2019). Capital Structure: Definition and Examples. Retrieved from https://www.thestreet.com/investing/earnings/capital-structure-14971332

Rahman, M. (2017). Time value of money: A case study on its concepts and its application in real life problems. International Journal of Research in Finance and Management, pp. 18-23. Bangladesh.

Stewart, B. (1991). The Quest for Value: A Guide to Senior Management. Harper \& Row. New York. Tuovila, A. (2020). Residual Value. Retrieved from https://www.investopedia.com/terms/r/residualvalue.asp 